\title{
A CSONTÁTTÉTKÉPZŐDÉS MOLEKULÁRIS ALAPJAI ÉS CÉLZOTT TERÁPIÁJA
}

\author{
Tímár József
}

Semmelweis Egyetem, II. sz. Patológiai Intézet, Budapest

A csontáttétképzés számos szolid daganat progressziójának jellegzetessége, mely kiváló példát szolgáltat az áttéti folyamat szervspecificitására. Megvalósulása mind a vénás, mind az artériás rendszeren keresztüli szóródás révén történhet. Az oszteolitikus vagy oszteoplasztikus áttétek keletkezése eltérő molekuláris útvonalakat feltételez, de a gyakorlatban a két folyamat keveredése révén zajlik. Mai tudásunk szempontjából alapvető jelentőségú az oszteoklasztok daganatsejtek általi aktiválódása és az ennek révén létrejövó csontreszorpció, mely a csontbomlás ördögi körének kialakulásához vezet. A csontáttétek kezelésében forradalmat jelentett az oszteoklaszt-csontmatrix kölcsönhatást gátló biszfoszfonátok felfedezése és klinikai sikere. A folyamat molekuláris alapjainak tisztázása azonban újabb terápiás célpontokat jelölt meg az oszteoklaszt-differenciálódásban, melyet a a TNF-receptorcsalád egyik tagja, a RANK-RANKligand rendszer szabályoz. Ennek az új terápiás megközelítésnek életképességét már sikeres klinikai vizsgálatok támasztják alá, melyekben RANKL-ellenes antitestet alkalmaztak. Ennek klinikai sikeressége tovább erösíti azt a nézetet, hogy a daganatokban zajló molekuláris történések pontos megismerése képezi az alapját az egyre hatékonyabb terápiás eljárások kifejlesztésének. Magyar Onkológia 54:59-64, 2010

Kulcsszavak: csontáttétképzés, molekuláris mechanizmus, célzott terápia

Formation of bone metastasis is a hallmark of the progression of several solid cancers, providing example for the organ specificity of the process. Bone metastasis may result in both venous and arterial dissemination. Though the molecular basis of the lytic and plastic bone metastasis formation is different, in reality these organ metastases represent a mixture of the two processes. The basis of bone metastasis formation is the activation of osteoclasts and the resulting bone resorption, initiating a vicious circle by activating the initiator cancer cell. The discovery of osteoclast-bone matrix interaction inhibitor bisphosphonates revolutionized the therapy of bone metastasis. Clarifying the molecular pathways involved in bone metastasis formation identified osteoclast differentiation as another feasible target. This process is under control of the TNF receptor family member RANK and its ligand RANKL. The feasibility of using this system to control bone resorption or cancer-induced skeletal events was proven clinically in trials using an anti-RANKL antibody. The clinical success of anti-RANKL antibody therapy provide further evidence that only precise identification of molecular pathways operational in cancers can lead to discovery of more effective (targeted) therapies. Tímár J. Molecular basis of bone metastasis formation and its targeted therapy. Hungarian Oncology 54:59-64, 2010

Keywords: bone metastasis, molecular mechanism, targeted therapy
Közlésre érkezett: 2010. január 28.

Elfogadva:

2010. február 10 .

\section{Levelezési cím:}

Dr. Tímár József

Semmelweis Egyetem

II. sz. Patológiai Intézet 1091 Budapest

Üllői út 93.

Telefon: (06-20) 825-9685

Fax: (06-1) 215-6921

E-mail:

jtimar@korb2.sote.hu

A munkát az Amgen Kft. támogatta.

\section{BEVEZETÉS}

A szolid malignus daganatok metasztatikus progressziójának alapja a "seed-and-soil” elmélet (4), ami a folyamat szervspecificitását fogalmazza meg. Ugyanakkor számos daganat esetében ez a folyamat érellátási illetve perfúziós sajátosságokkal (is) magyarázható. A korábbi vizsgálatok viszonylag kisszámú esetet elemeztek, így következtetéseik esetleg megkérdőjelezhetőek voltak. Most egy 6 millió beteget érintő Medicare-adatbázis alapján a kérdést imformatikailag újraelemezték (2) 43 primer tumorfajta vonatkozásában, ahol 27 metasztázis-szervet elemeztek (a nyomonkövetés minimálisan 48 hónap volt). A legtöbb adat a prosztata-, tüdő-, emlő-, vastagbél- és húgyhólyagrákokról illetve melanómáról állt rendelkezésre. Az egyik fontos megfigyelés az volt, hogy a szervi áttétek gyakorlatilag 2 hullámban keletkeznek: ún. korai és késői formában, ami alól kivétel a melanóma (késői) és a tüdőrák (korai). Az egyes daganatok szervspecificitását tekintve csodák nincsenek: a prosztatarák csontmetasztázis-specifikus daganat 
(folyamatos), az emlőrák a csont mellett (folyamatos) késői máj- és tüdőáttétképzéssel jellemezhető. A tüdőrák a csont mellett máj- és tüdőáttétképzéssel, míg a vastagbélrák folyamatos májáttétképzéssel és késői tüdőáttétekkel jellemezhető. Érdekes módon a húgyhólyagrák szintén folyamatos csontáttétképzésü és kéthullámú tüdő- és májáttétképző.

A szervi áttétképzés új elmélete, amit kísérleti rendszerben igazoltak, az ún. metasztatikus bölcső kialakulása (7). Ismert az, hogy a malignus daganat által termelt citokinek stimulálják a csontvelőt, amelyből őssejtek (hematopoetikus, hemangiopoetikus, stb.) áramlanak ki és jutnak el az egyes szervekbe. A citokinek közül értelemszerüen az angiogén faktorok (pl. VEGF) vagy TNF $\alpha$, IL-6, EGF, HGF, stb. játszhatnak fontos szerepet. Ezek a faktorok pl. a metasztázis helyén megemelik a fibroblasztok fibronektin termelését lokálisan az áttét kialakulása előtt, a tüdő endotélsejtjeiben pl. kemoattraktánsok termelődnek (S100A8/9 vagy szérum amyloid, SAA). Elöfordulhat az is (emlörák), hogy a tumor enzime, a LOX a metasztázis kollagénjét keresztköti. Mindezen mikromilieu-változások kedvezőek a csontvelői prekurzorok nem véletlenszerü kitapadásához a keringésből (Mac1+, CD11b+, endotél-progenitorok). Ezek a megváltozott matrixú csontvelői segítőket tartalmazó gócok azok a helyek, ahol a keringésből a daganatsejtek is előszeretettel tapadnak ki. A szervek felismerésének egy másik útja a kemokinek és receptoraik révén történő felismerés: emlőrák esetében a daganatsejtek CXCR4-pozitivitása elősegíti a tüdő-, de főleg az agyi áttétek kialakulását a lokális CXCL12 ligandot használva segítségül $(1,8)$. Egy másik lehetséges út, hogy a csontáttétképző daganatok sejtjei csontspecifikus matrixot termelnek (OPN, ON, BSP), ami segít az új szervben való megtelepedésben.

Ettől azonban nem lesz a daganatsejtekből áttét. A szervekbe (pl. csont) kikerülő daganatsejtek általában nyugvó állapotba kerülnek, aminek oka az ún. metasztázis-szuppresszor gének működése: a KISS1 (G0-stop), a KAI1 proliferáció-gátló hatású, az NM23H1 és az MKK4/7 a kezdetben meginduló proliferációt állítják le a mitogén jelpályák blokkolásával. A daganatok bizonyos genetikai sajátosságai szintén fontosak lehetnek a szervi áttétek kialakulásában: emlőrákban az ER+/PgR- fenotípus ilyen specifikus prognosztikus tényező (18).

\section{A CSONTÁTTÉTKÉPZÉS PATOMECHANIZMUSA}

A csontáttétképzés alaplépései megegyeznek a hematogén áttétképzés folyamatának lépéseivel, kisebb eltérések vannak csak, amelyek csakis és kizárólag a csontra jellemzők. A primer daganat ereződése alapfeltétele a hematogén áttétképzésnek és így a csontáttétképzésnek is, mert a primer daganatban lévő tumorsejtek a daganatot ellátó, ill. daganatközeli erek falán átlépve ahhoz kitapadva, lebontva, majd azon keresztülvándorolva jutnak be a keringésbe. Ez az intravazációs folyamat elsősorban a venózus posztkapilláris vénákat érinti. A tüdő esetében a vena pulmonalis rendszere gyakorlatilag az artériás szisztémás keringésbe juttatja a daganatsejteket. Az egyik leggyakoribb csontáttétet képző daganat, a prosztatarák esetében az ún. periprosztatikus vénás plexus elvezetése juttatja el a lumbális, lumboszakrális csigolyák közvetlen közelébe a daganatsejteket, amelyek ott az ún. Batson-vénák révén kerülnek kapcsolatba a csontokkal, ill. a csontállománnyal.

A csontáttétek kialakulása azonban döntően az artériás rendszeren keresztül történik. Az artériás rendszer végén lévő kapillárishálózat a csontokba vezeti a daganatsejteket, amelyek a csontvelő sinusoidjáig jutnak. A csont szinuszoidrendszere igen egyszerü, nagymértékű hasonlóságot mutat a máj és a nyirokerek szinuszoidjaihoz. Mindhármójuk közös vonása, hogy igen vékony, majdnem virtuális bazális membrán határolja az endotélsejteket, maguk az endotélsejtek nem fenesztráltak, a keringésben lévő, ill. a lokális szervben lévő kémiai faktorok gyakorlatilag szabadon jutnak át, így a daganatsejtek számára fontos információk anélkül elérhetők, hogy a daganatsejtek átléptek volna a szinuszoidok falán. Természetesen az is nagy előny, hogy szemben más szervek érstruktúrájával, a csont szinuszoidjaiból történő extravazációs folyamat csak migrációs, ill. kemotaktikus képességet tételez fel. Természetesen a csontvelőbe történő kilépés után jellegzetes és különleges extracelluláris, ill. sejtes kölcsönhatások lépnek fel. A folyamat a klasszikus mag és talaj találkozása eseményeinek elemzését igényli. A csont szinuszoidjaiba történő extravazáció után előbb-utóbb a daganatsejtek a csontvelő/csontgerendák határához vándorolnak. A csontgerendák egyrészt különleges matrixstruktúrát jelentenek, talán a legkeményebb mechanokémiai ellenállást jelentik, amivel egy daganatsejt szembesülhet, hiszen jelentősen mineralizált alapállományról van szó (1. ábra).

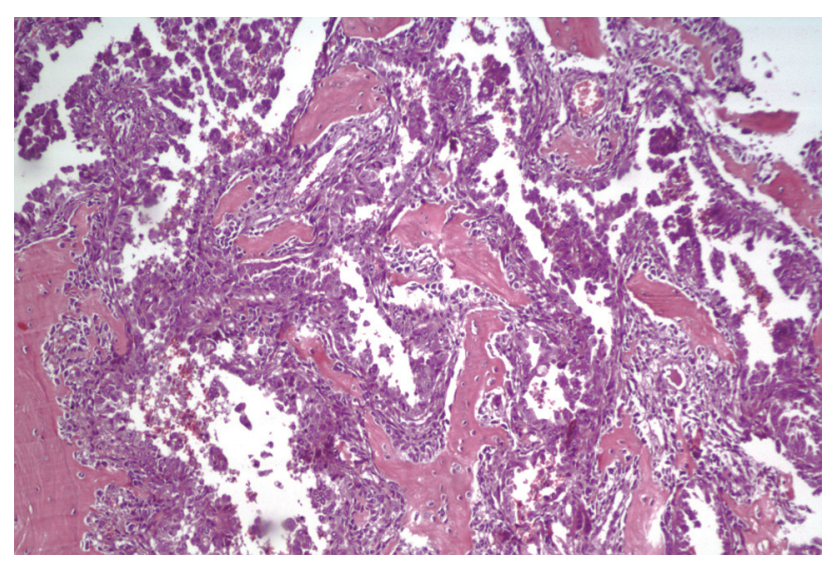

1. ábra. Nem-kissejtes tüdőrák csontáttétének szövettani képe. HEE festés 
Ugyanakkor a daganatsejtek számára könnyebbséget jelenthet az, hogy a csont állandó átépülésben van fiziológiásan is, ezt az átépülést tulajdonképpen a folyamatos lebomlás és felépülés ciklusai jelentik, amelynek két fő gazdasejti tényezője van, az oszteoklasztok és az oszteoblasztok. A daganatsejtek mind az oszteoklasztokat, mind az oszteoblasztokat felhasználják arra, hogy a csontgerendákat átépítsék, és gyakorlatilag a csontáttétképzés folyamatának molekuláris mechanizmusai e sejtekkel kialakuló molekuláris kölcsönhatások sajátosságaiból épülnek fel.

\section{A CSONTÁTTÉTEK FORMÁI: AZ OSZTEOLITIKUS ÉS AZ OSZTEOPLASZTIKUS ÁTTÉTEK}

Régóta ismert, hogy a rosszindulatú daganatok áttétei két formában nyilvánulnak meg. Az egyik esetében a csontban növekedő áttét folyamatosan lebontja a környező csontgerendákat; ez a folyamat az érintett csont anatómiai struktúrájának súlyos destrukcióját idézi elő és utóbb patológiás csonttöréshez vezet. Általában igen jelentős fájdalommal jár, hiszen a mechanikus terhelést ezek a csontok nem viselik el. Oszteolitikus áttétet tipikusan az emlőrák képez. Korábban azt gondolták, hogy az oszteolitikus áttétképzéskor a daganatsejtek maguk képesek olyan bontóenzimeket előállítani, amelyek a csont lebontására alkalmasak, de ez a teória régen megdőlt. Az oszteolitikus áttétek kialakításához a daganatsejtek az oszteoklasztokat használják fel $(13,15,20)$, tehát ezt az áttétképzést oszteoklasztos áttétképzésnek is lehet nevezni (2. ábra). Ez esetben a fiziológiás csontlebontási folyamat mechanizmusát erősítik fel a daganatsejtek megfelelő kémiai mediátorok révén. A másik lehetőség az, hogy az áttétek oszteoplasztikusak, tehát a kialakuló tumorsejtfészkek körül csont-újdonképződés indul meg $(13,15,20)$. Miután a csont felépítését az oszteoblasztok vezénylik és hajtják végre, az oszteoplasztikus áttétképzés gyakorlatilag oszteoblasztikus áttétképzést jelent. A daganatsejtek az oszteoblasztok aktiválása révén képeznek maguk körül új, de autentikus lokális

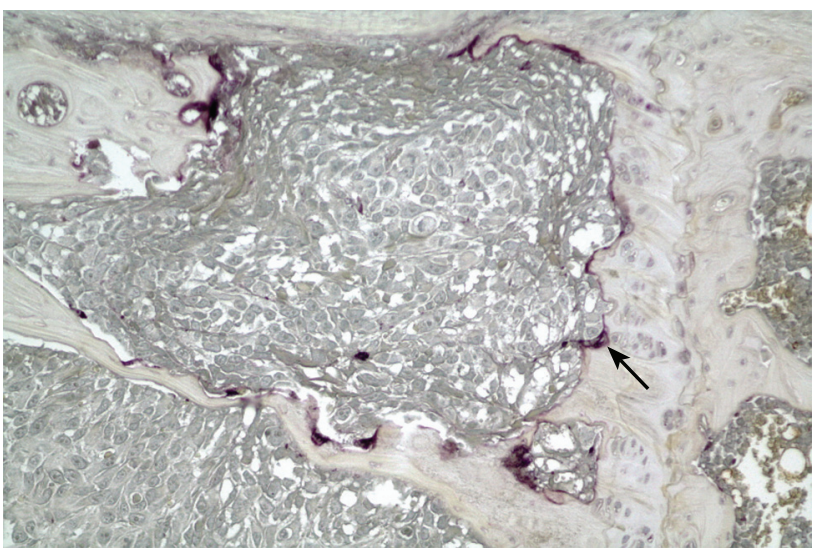

2. ábra. Emlőrák csontáttétében oszteoklaszt jelölése (nyíl). Savas foszfatáz-reakció (lila) csontmatrixot. Az oszteoblasztikus áttétképzés során a csont bár átépül, de anatómiai stabilitása jelentősen nem károsodik, tehát a klinikai szövődmények kevésbé súlyosak egy ideig, szemben az oszteolitikus áttétekkel. Természetesen több daganatféleség esetében a kétféle folyamat nem kizárólagosan zajlik, és akár egy áttéti góc esetében is van litikus és plasztikus terület, azaz a mechanizmusok átfedhetnek attól függően, hogy a klasztokat és blasztokat stimuláló faktorok vannak-e többségben az adott daganatban.

Érdemeselemeznünka kétáttétképzési mechanizmus molekuláris részleteit azért, mert ezek során világossá válik az, hogy milyen lehetséges beavatkozási pontok tárulhatnak elénk, hogy a folyamatokat befolyásolni tudjuk. Fiziológiásan a csont felépülésének folyamatát az oszteoblasztok irányítják a csont-morfogenikus fehérjék (BMP-k) valamint alapvető növekedési faktorok, mint a TGF $\beta$, IGF és az FGF segítségével. Ezt a folyamatot elsősorban a PTH (parathormon) befolyásolja pozitívan, de prosztaglandinok illetve citokinek is képesek erre, míg a kortikoszteroidok negatív szabályozók. Az oszteolitikus folyamat az oszteoklasztok aktiválásán ill. gátlásán keresztül valósul meg, ahol a PTH, D3 vitamin, valamint az IL-1, IL-6, IL-17, a RANK-ligand, bizonyos prosztaglandinok aktiválók, míg kortikoszteroidok, a prosztaglandin E2, az IL-4, IL-18, és az IFN $\gamma$, a TGF $\beta$, az OPG gátló hatású $(13,15,20)$.

A litikus folyamat szempontjából a legnagyobb jelentősége a RANK-ligandnak van, melynek sejtfelszíni receptora a RANK. Fontos tudni azonban, hogy létezik egy ún. szolúbilis formája is a RANKL receptorának, ez az oszteoprotegerin (OPG). A RANK a tumornekrózis-faktor (TNF) receptorcsalád tagja. Az oszteolitikus áttéteket azok a tumorsejtek képesek kezdeményezni, amelyek PTHrP parathormon-szerü peptidet képesek szekretálni (az emlőrákok 50\%-a). Ez a peptid a stromális sejteket és oszteoklaszt-prekurzorokat aktiválja és differenciálódásra serkenti, amihez ezek a sejtek elkezdik expresszálni a RANKL-ot. Az aktiválódó oszteoklasztok elkezdik lebontani a csontmatrixot és felszabadítják az abban inaktív állapotban lévő növekedési faktorokat (TGF $\beta-t$, IGF-et és az FGF-et). A felszabaduló TGF $\beta$ és Ca++ aktiválja a tumorsejteket, amelyek újabb citokineket és PTHrP-t termelnek, így circulus vitiosus alakul ki, az egyre inkább aktiválódó oszteoklasztok egyre nagyobb csontlebontást idéznek elő és tovább aktiválják a daganatsejteket, és így előbb-utóbb oszteolitikus folyamat indul be $(13,15)$. A PTHrP mellett a tumorsejtek több olyan faktort is szekretálnak, amelyek a fiziológiás csontlebontás pozitív stimulálói, így az IL-6-ot, a prosztaglandinE2-t, az IL-1-et, vagy TNF $\alpha$-t. Az oszteoklasztok felszínén az $\alpha \mathrm{v} \beta 3$ integrin expresszálódik, amely a csont sajátos matrixfehérjéi közül az oszteonektint $(\mathrm{ON})$, az oszteopontint (OPN) és a többi matrixligandot is fel képes ismerni, és ezzel biztosítja, hogy az oszteoklaszt megfelelő alapállományba ágyazódjon be.

$\mathrm{Az}$ oszteoplasztikus áttétképzés folyamata kevésbé jól karakterizált molekuláris szempontból $(13,15)$. 
Újabb vizsgálatok arra utalnak, hogy egyik kulcsfaktora a daganatsejtek által termelt endotelin-1. Emellett a trombocita növekedési faktor, a PDGF is fontos szerepet tölthet be, és egyértelmüen igazolódott, hogy a daganatsejtek által nagyon gyakran fokozottan termelt plazminogénaktivátor, az urokináz forma (uPA) fontos szerepet játszik. Ebből a szempontból fontos proteáz még a PSA, amely kallikrein-szerű proteáz. A PSA képes bontani a PTHrP-t és így akadályozhatja a csont lebontását. Ugyanakkor a PSA képes az oszteoblasztok aktiválására, annak révén, hogy ez a proteáz (és a többi segítő proteáz) felszabadítja a csontban lévő növekedési faktorokat, mint az IGF1,2 , vagy TGF $\beta$, és ezek indítják el az oszteoblasztok proliferációját.

\section{A CSONTÁTTÉTKÉPZÉS MOLEKULÁRIS GENETIKÁJA}

A csontáttétképzés olyan különleges képességet feltételez a daganatsejtek részéről, amely ebben a különleges matrixkörnyezetben való túlélést eredményezheti, hogy ehhez különleges genetikai képesség is szükséges, és ezt esetleg oszteogenetikus mimikrinek nevezhetjük. Ez alatt azt értjük, hogy a daganatsejtek olyan matrixfehérjéket expresszálnak, amelyek máskülönben csak a csontban vannak jelen. Régóta ismert az a tény, hogy elsősorban a csontokba gyakran áttétet képző daganatok, mint emlőrák, prosztatarák, tüdőrák esetében figyelték meg, hogy csont-morfogenetikus fehérjéket (BMP), oszteopontint (OPN), oszteonektint (ON) képesek expresszálni, valamint ezek azok a daganatok (elsősorban az emlő- és prosztatarák), amelyek a PTHrP-t is expresszálják $(13,15,20)$. Ez a jellegzetes genetikai karakter biztosítja a daganatsejteknek azt a képességét, hogy abban a különleges matrixkörnyezetben, amit a csont jelent, túléljenek.

Korszerú molekuláris genetikai genomikai vizsgálatok a közelmúltban fényt derítettek arra, hogy milyen genetikai képességekkel rendelkezhetnek azok a daganatok, amelyek szelektíven a csontokba képesek áttétet képezni. Az ilyen képességű emlőráksejtek fokozottan expresszálják az oszteoklasztokat aktiváló IL11 citokint, az oszteoklasztok aktiválása során szerepet játszó matrixfehérjét, az oszteopontint, a csontáttétek sajátos vaszkularizáltságát elindító angiogenetikus faktort, az FGF5-öt és a CTGF-et (kötőszöveti növekedési faktor), a matrixlebontásban iniciáló szerepet játszó MMP-1 kollagenázt és a daganatsejteket a csontban termelődő kemokinek felismerésére képessé tevő receptort, a CXCL4-et (9). A további klinikai vizsgálatok megerősítették ezeket a megfigyeléseket, de a mintázatot néhány más matrixfehérje, mint a PRG1, az I. típusú kondroitinszulfát-proteoglikán, a trombospondin-1 angiogenezis-szabályozó fehérje, az amiloid-A2, a follisztatin és az MHCII-DR/DP egészítette ki (12).

\section{A CSONTÁTTÉTEK CÉLZOTT KEZELÉSE}

$$
\text { A jelen }
$$

A biszfoszfonátok (BP) voltak az első ún. célzott csontáttét-ellenes gyógyszerek, melyek példát mutattak a szervi áttétképzés folyamatának befolyásolására. A klasszikus nem-amino-BP-k metilálódnak a szervezetben (csontban) és ezzel stabil ATP-analóggá válnak, és miután ez az oszteoklasztokban történik, elsődleges celluláris célpontjuk ez a sejt, aminek biológiai következménye csontstabilizáció. Az amino-BP-k, bár kémiailag hasonlóak és szintén elsősorban a csontokban akkumulálódnak, kevésbé hatékonyan metilálódnak, azonban egy másik kémiai tulajdonsággal is rendelkeznek: hatékony inhibitorai a farnezilpirofoszfátszintáznak $(5,14)$. A jelátvitelben szereplő fehérjék (pl. RAS, RHO, RAC, RAB) egy részének aktív működéséhez a plazmamembránhoz kell kikötődniük, ami lipidmódosuláson (preniláción) keresztül történik (19). A prenilációs folyamat farneziláció és/vagy geraniláció formájában történhet, mely az egyes fehérjék esetében specifikusan (nem véletlenszerüen) történik és transzferázok végzik (19). A RAS fehérjék mindkét módon aktiválódhatnak, a RHO-B csak farnezilációval, a többi RHO fehérje csak geranilációval. Fontos megjegyezni, hogy a cdc42 is geraniláció révén aktiválódik. Ugyanakkor a farneziláció fontos a magi lamin fehérje múködése szempontjából, és a mitotikus orsófehérjék egy része is farnezilálódik (CENP-k). Mindezek alapján egyértelmű, hogy amennyiben e prenilálódó fehérjék aktivitását preniláció révén kívánnánk befolyásolni, azt a transzferázok révén csak bizonyos fehérjék esetében lehet elérni, melyek egyoldalúan használják ezt a mechanizmust, a jelátviteli fehérjék többsége mindkét transzferázrendszert képes használni, így nem elegendő az egyik gátlása. A prenilációs folyamat leghatékonyabb általános gátlószerei manapság az aminobiszfoszfonátok, melyek a specifikus transzferázok belépése előtt már felfüggesztik a prenilációhoz szükséges szubsztrátok termelését (16).

$\mathrm{Az}$ első generációs biszfoszfonátcsaládba tartozó clodronát a malignus tumorok litikus csontáttéteinek és a hiperkalcémiának kezelésére kerül alkalmazásra. Az aminobiszfoszfonát ibandronát és zoledronsav a daganat-indukált hiperkalcémia kezelése mellett a csontáttétes betegek csontszövődményeinek megelőzésére használatos. Újabban előrehaladott klinikai vizsgálatok zajlanak annak igazolására, hogy a zoledronsav képes megelőzni emlőrák és prosztatarák esetében a csontáttétek kialakulását is (10).

\section{A jövó}

Mint azt korábban említettem, a parathormon-szerű fehérje (PTHrP) a daganatsejtekben az egyik fö tényező bizonyos típusú rákok csontáttétképző képességében. 
1. táblázat. A csontáttétképzés célzott terápiájának lehetôségei

\begin{tabular}{|c|c|c|c|c|c|}
\hline Szer & Molekuláris célpont & Sejtes célpont & Oszteoporózis & Csontáttét & $\begin{array}{l}\text { Csontáttét- } \\
\text { megelőzés }\end{array}$ \\
\hline Biszfoszfonátok & ATP & oszteoklaszt & gátló & gátló & $?$ \\
\hline Amino-biszfoszfonátok & preniláció ATP & $\begin{array}{l}\text { oszteoklaszt } \\
\text { daganatsejt }\end{array}$ & gátló & gátló & igen \\
\hline Denosumab antitest & RANKL & oszteoklaszt & gátló & gátló & $?$ \\
\hline Kismolekulájú inhibitor & katepszin-K & oszteoklaszt & gátló (preklinikai) & gátló (preklinikai) & $?$ \\
\hline $\begin{array}{l}\text { AZD0530 } \\
\text { SKI-606 }\end{array}$ & SRC & $\begin{array}{l}\text { oszteoklaszt } \\
\text { daganatsejt }\end{array}$ & gátló (preklinikai) & gátló (preklinikai) & $?$ \\
\hline Bortezomib & proteaszóma & $\begin{array}{l}\text { oszteoklaszt } \\
\text { daganatsejt }\end{array}$ & gátló (preklinikai) & gátló (preklinikai) & $?$ \\
\hline Zibotentan & endotelin-A- receptor & daganatsejt & & gátló (preklinikai) & $?$ \\
\hline Cilengitid & $\alpha v \beta 3$ integrin & $\begin{array}{l}\text { oszteoklaszt } \\
\text { daganatsejt }\end{array}$ & gátló (preklinikai) & gátló (preklinikai) & $?$ \\
\hline
\end{tabular}

RANKL $=$ RANK-ligand, SRC $=$ sarc-onkogén

Kísérleti rendszerekben az ez ellen termelt antitest (CAL) meggátolta a daganatsejtek oszteolitikus áttétképzését. Ilyen antitestet klinikai fázis I vizsgálatban is teszteltek már (11).

A csontlebontó circulus vitiosus fontos faktora a TGF $\beta$, illetve a PDGF, amely a csontmatrixból kerül felszabadulásra az oszteoklasztok aktivitása révén. Állatkísérleti modellekben mind a TGF $\beta$-t gátló kismolekulájú inhibitorok, mind a PDGF-receptort blokkoló sunitinib képes volt gátolni az oszteolitikus folyamatokat (11).

Új típusú megközelítés az oszteoklaszt-differenciáció gátlása. Mint ahogy a korábbi fejezetekben bemutattam, az oszteoklasztok differenciálódásában alapvető szerepet játszik a RANK, annak ligandja (RANKL), valamint az oszteoprotegerin. A denosumab (ANG 662) humanizált monoklonális antitest, amelyet a RANK-ligand ellen fejlesztettek ki. Fázis III vizsgálatokban metasztatikus csontáttétekkel rendelkező daganatos betegek esetében illetve posztmenopauzális oszteoporózisban tesztelték hatását. A denosumab hoszszú felezési idővel rendelkezik a keringésben. Biológiai hatása kiterjedt csontreszorpció-gátló hatásban nyilvánul meg, ezt posztmenopauzális nőbetegek esetében és csontáttétes betegek esetében is kimutatták $(3,17)$. A csontáttétes betegek egy része a biszfoszfonát-terápia ellenére progrediál, aminek érzékeny biomarkere a kollagén-eredetű N-telopeptid vizeletürítése. Egy fázis II vizsgálatban az ilyen betegek aminobiszfoszfonátkezelését denosumabra váltották. A denosumabadagolás az esetek többségében csökkenteni volt képes a csontreszorpció markerét (N-telopeptid vizeletszintjét), míg a biszfoszfonát ezt csak a betegek harmadában érte el. Ami azonban még érdekesebb, hogy a követési periódusban felére csökkent a csontrendszert érintő események aránya a denosumab karon a biszfoszfonát karhoz képest (6), ami arra utal, hogy a RANKL elleni terápia esetleg hatékony lehet a biszfoszfonát-rezisztens csontáttétek esetében. Érdekes, hogy a denosumab adagolása szubkután történik és ezzel új utat mutat az antitestterápiák számára, hiszen eddig ezeket csak iv. adagolták.

Egy másik megközelítési lehetőség az oszteoklasztok jelátviteli folyamatainak befolyásolása. Lehetséges terápiás target a katepszin-K-t bontó enzim, amely az oszteoklasztokban magas szinten fejeződik ki, és az III-es típusú kollagén lebontásában játszik fontos szerepet. Az oszteoklasztok által indukált csontlebontásnak két célpontja van, a kalciumhidroxiapatit kristályok és a proteinmatrix bontása. A katepszin-K ellen számos kismolekulájú inhibitort fejlesztettek ki, amelyek állatkísérleti modellekben képesek voltak a csontreszorpciót blokkolni (11) (1. táblázat).

Az oszteoklasztok jelátviteli pályáinak közös jellemzője, hogy ezek az SRC onkogénen keresztül aktiválódnak. Érdekes módon, ha egészséges kísérleti állatokban az SRC onkogént kikapcsolják, ezekben az állatokban oszteopetrózis alakul ki, mert a csont reszorpciós folyamatai gátoltak. Kis molekulájú SRC-inhibitorok rendelkezésre állnak már, és ezeket különböző kísérleti modellekben is tesztelték, sőt fázis I-II vizsgálatokban is vizsgálták már. Célszerű volna ezek specifikus csontáttétképzést befolyásoló szerepét is tesztelni. Az oszteoklasztok gyulladásos citokin-termelésének egyik kulcs jelátviteli pontja a MAP-kináz aktiválódása, amely eredménye az interleukin-1 és TNF $\alpha$ termelése, amely tovább fokozza a csontreszorpciós folyamatot. MAP-kinázgátló szereket elég széles körben alkalmaznak kísérleti rendszerekben, és ezek egyik fontos biológiai hatása, hogy gátolják az oszteoklasztok aktivitását és a csontreszorpció folyamatát.

A citoplazmai proteinek eliminálásának egyik útja a proteaszomális lebomlás. Érdekes biológiai jelenség, hogy a proteaszóma funkciójának gátlása stimulálja az oszteoblasztok funkcióit, míg gátolja az oszteoklasztok differenciálódását. Bár kísérleti rendszerekben a pro- 
teaszóma-gátló szerek, mint pl a bortezomib, képesek voltak az oszteoklasztok funkcióját gátolni, az ilyen proteaszóma-inhibitorokat csontáttétek, vagy oszteoporózis kezelésére még nem tesztelték klinikai rendszerekben (11).

Egy továbbilehetséges támadáspontazoszteoklasztok matrixkapcsolatának felfüggesztése. Az oszteoklasztok a csontmatrix fehérjéit a vitronektin receptoron keresztül ismerik fel ( $\alpha \mathrm{v} \beta 3$ integrin). Az integrin aktiválódása oszteoklaszt-aktiválódáshoz vezet, amelynek eredménye a katepszinek, többek között a katepszin-K felszabadulása. A vitronektin receptor funkciójának blokkolására specifikus $\alpha v \beta 3$ integrin elleni antitesteket, kis molekulájú inhibitorokat, illetve RGDS peptideket állítottak elő, amelyek állatkísérleti modellekben képesek voltak az oszteoklasztok aktivitását blokkolni (11).

Prosztatarákok gyakran képeznek oszteoblasztikus áttéteket. Ennek molekuláris mechanizmusát vizsgálva kiderült, hogy a prosztataráksejtek nagy mennyiségben termelnek egy endotelin-1 nevű citokint, amelynek receptora az endotelin-A-receptor. Ennek vaszkuláris hatásai mellett oszteoblaszt-aktiváló hatása van. Kísérleti rendszerekben egyértelmüen bebizonyosodott, hogy az endotelin-A-receptor blokkolása humán prosztatarákok esetében gátolja az oszteoblasztikus metasztázisképződést. Több endotelin-A-receptort gátló szer is kifejlesztésre került, részben antitest, részben kis molekulasúlyú inhibitor, amelyek klinikai hasznosítására fázis II-III vizsgálatok zajlanak (11).

\section{ÖSSZEFOGLALÁS}

Az elmúlt évtizedet a csontáttétek kezelésében a biszfoszfonátok évtizedének is lehet nevezni, hiszen a malignus daganatok által okozott csontelváltozások kezelésében egyeduralkodóak voltak. Ez az évtized azonban jelentősen kiszélesítette ismereteinket a csontáttétek keletkezésének molekuláris mechanizmusáról, aminek eredményeként számos új terápiás célpont körvonalazódott. A RANKL elleni antitest első sikeres klinikai alkalmazásai, esetleg első lépésben a biszfoszfonátrezisztens esetekben, azzal kecsegtetnek, hogy újabb terápiás eszközzel gazdagodhat az onkológia fegyvertára, ami tovább erősítheti a célzott terápiák alkalmazása iránti bizalmat.

\section{IRODALOM}

1. Ben-Baruch A. Organ selectivity in metastasis: regulation by chemokines and their receptors. Clin Exp Metastasis 25:345-356, 2008

2. Chen LL, Blumm N, Christakis NA, et al. Cancer metastasis networks and the prediction of progression patterns. Br J Cancer 101:749-758, 2009

3. Cummings SR, San Martin J, McClung MR, et al. Denosumab for prevention of fractures in postmenopausal women with osteoporosis. N Engl J Med 361:756-765, 2009

4. Fidler IJ, Poste G. The "seed and soil" hypothesis revisited. Lancet Oncol 9:808, 2008

5. Finley RS. Bisphosphonates in the treatment of bone metastases. Semin Oncol 29(1 Suppl 4):132-138, 2002

6. Fizazi K, Lipton A, Mariette X, et al. Randomized phase II trial of denosumab in patients with bone metastases from prostate cancer, breast cancer, or other neoplasms after intravenous bisphosphonates. J Clin Oncol 27:1564-1571, 2009

7. Gao D, Mittal V. The role of bone-marrow-derived cells in tumor growth, metastasis initiation and progression. Trends Mol Med 15:333-343, 2009

8. Hinton CV, Avraham S, Avraham HK. Role of the CXCR4/CXCL12 signaling axis in breast cancer metastasis to the brain. Clin Exp Metastasis 27:97-105, 2010

9. Kang Y, Siegel PM, Shu W, et al. A multigenic program mediating breast cancer metastasis to bone. Cancer Cell 3:537-549, 2003

10. Kopper L, Tímár J, Becságh P, Nagy Zs. Célzott diagnosztika és célzott terápia az onkológiában. ISBN 978963987959 1. Semmelweis Kiadó, Budapest, 2009

11. Lipton A. Future treatment of bone metastases. Clin Cancer Res 12:6305s-6308s, 2006

12. Minn AJ, Kang Y, Serganova I, et al. Distinct organ-specific metastatic potential of individual breast cancer cells and primary tumors. J Clin Invest 115:44-55, 2005

13. Mundy GR. Metastasis to bone: causes, consequences and therapeutic opportunities. Nat Rev Cancer 2:584-593, 2002

14. Paterson AH. Adjuvant bisphosphonate therapy: the future. Semin Oncol 28( 4 Suppl 11):81-85, 2001

15. Roodman GD. Mechanisms of bone metastasis. N Engl J Med 350:1655-1664, 2004

16. Santini D, Caraglia M, Vincenzi B, et al. Mechanisms of disease: preclinical reports of antineoplastic synergistic action of bisphosphonates. Nat Clin Pract Oncol 3:1-14, 2006

17. Smith MR, Egerdie B, Hernandez Toriz N, et al. Denosumab in men receiving androgen-deprivation therapy for prostate cancer. N Engl J Med 361:745-755, 2009

18. Wei B, Wang J, Bourne $\mathrm{P}$, et al. Bone metastasis is strongly associated with estrogen receptor-positive/progesterone receptor-negative breast carcinomas. Hum Pathol 39:1809-1815, 2008

19. Winter-Vann AM, Casey PJ. Post-prenylation-processing enzymes as new targets in oncogenesis. Nat Rev Cancer 5:405-412, 2005

20. Yoneda T, Hiraga T. Crosstalk between cancer cells and bone microenvironment in bone metastasis. BBRC 327:679-687, 2005 